\title{
Pengaruh Konsumsi Buah Kurma Terhadap Peningkatan Kadar Hemoglobin Pada Ibu Hamil Trimester III
}

\author{
Sugita $^{1}$, Kuswati ${ }^{2}$ \\ Poltekkes Kemenkes Surakarta \\ *Email : gitabesar@yahoo.com
}

\begin{abstract}
Background: Anemia in pregnant women is a condition of the mother with hemoglobin levels in her blood $<11.0 \%$ gr. Prevention of anemia in pregnant women can be through various ways including the fulfillment of nutrients in the body obtained from fruits and vegetables, one of them by consumption of dates. Dates contain $1.02 \mathrm{mg}$ of iron per 100 grams. This study aims to determine the effect of consumption of dates on the increase in hemoglobin levels in third trimester pregnant women in the Klateng Community Health Center. Method: This type of research is a quasy experiment with a non equivalent control group design pre-test-post test design. A population of 57 third trimester pregnant women The sampling technique used was purposive sampling, a sample of 30 respondents from third trimester pregnant women was obtained in the working area of the Central Health Center in Klateng. The data analysis technique used is the Wilcoxon Sign Rank Test. Results: The average level of hemoglobin in the treatment group of hemoglobin levels pre (before) the administration of dates by $10.793 \mathrm{gr} / \mathrm{dL}$ and post (after) the administration of dates occurred an increase of 11,933 $\mathrm{gr} / \mathrm{dL}$ and seen an increase (difference) from the average value of pre and post of $1,140 \mathrm{gr} / \mathrm{dL}$ with a standard deviation of 0.6643. Statistical test results obtained p value $<0.05$ (0.002 <0.05) so that Ho is rejected, Ha is accepted then consumption of dates has a statistically significant effect on increasing hemoglobin levels. Conclusion: From the results of these studies indicate the influence of consumption of dates to increase hemoglobin levels in third trimester pregnant women in the work area of the Central Health Center.
\end{abstract}

Keywords: effect of dates, hemoglobin, trimester III pregnant women

\section{PENDAHULUAN}

Anemia pada ibu hamil adalah kondisi ibu dengan kadar hemoglobin (Hb) dalam darahnya $<11,0$ gr\% sebagai akibat ketidakmampuan jaringan pembentuk Sel darah merah (Erythropoetin) dalam produksinya untuk mempertahankan konsentrasi $\mathrm{Hb}$ pada tingkat normal (WHO,2011).

Anemia pada ibu hamil merupakan masalah yang banyak terjadi di Indonesia. Anemia bisa terjadi pada semua usia. Di Indonesia prevalensi anemia masih tinggi, insiden anemia $40,5 \%$ pada balita, $47,2 \%$ pada usia sekolah, $57,1 \%$ pada remaja putri dan 50,9\% pada ibu hamil ( Riskesdas 2013). Anemia merupakan dampak dari masalah gizi dan merupakan salah satu penyebab kejadian perdarahan pada saat persalinan.

Sebagian besar anemia disebabkan karena kurangnya asupan zat besi (defisiensizatbesi).(Almatsier,2009).

Penanggulangan anemia pada ibu hamil dapat melalui pemenuhan nutrisi dalam tubuh yang diperoleh dari dalam buah buahan serta sayuran, salah satunya dengan konsumsi buah kurma yang mengandung 13,7 $\mathrm{mg}$ zat besi (per 100 gram). (Satuhu, 2010). Peran Bidan sesuai dengan ruang lingkup standar asuhan kebidanan no 6, yaitu pengelolaan anemia pada kehamilan, dimana bidan melakukan tindakan pencegahan, penemuan, penanganan dan atau rujukan semua kasus 
anemia pada kehamilan sesuai dengan ketentuan yang berlaku. Berdasarkan Studi Pendahuluan yang dilakukan di Dinas Kesehatan Kabupaten, data Ibu hamil Anemia tertinggi pada tahun 2017 terdapat di wilayah kerja Puskesmas Klateng. Studi pendahuluan mendalam yang dilakukan diwilker Puskesmas Klateng pada tanggal 13- 14 Desember 2018, bahwa ibu hamil yang melakukan pemeriksaan K1 selama kurun waktu Januari 2018-Oktober 2018 sejumlah 491 orang dan yang mengalami ane- mia sejumlah 281orang. Untuk data ibu hamil baru K1 pada bulan Desember 2018 sejumlah 54 orang, dari sejumlah 54 orang tersebut 25 orang ibu hamil mengalami anemia.

Berdasarkan hasil wawancara di wilayah kerja Puskesmas Klateng, penyebab ibu hamil tidak mau mengkonsumsi dan tidak teratur konsumsi tablet Fe dikarenakan efek samping yang ditimbulkan akibat konsumsi tablet Fe. Hal ini merupakan salah satu kasus yang harus segera dicari pemecahan masalahnya. Dengan dilakukan penelitian ini, diharapkan dapat dijadikan salah satu solusi alternatif untuk memperbaiki kondisi ibu hamil dengan anemia tanpa efek samping yang menimbulkan ketidaknyamanan pada ibu hamil.

Berdasarkan uraian latar belakang tersebut peneliti tertarik untuk melakukan penelitian tentang Pengaruh Konsumsi Buah Kurma Terhadap Peningkatan Kadar Hemoglobin Pada Ibu Hamil TM III.

\section{METODE PENELITIAN}

Jenis penelitian ini adalah quasy eksperimental dengan rancangan nonequivalent control group yaitu dengan melihat hasil peningkatan kadar hemoglobin sebelum dan sesudah treatment konsumsi buah kurma.

Penelitian ini dilakukan di Wilayah kerja Puskesmas Klateng mulai dari April - September 2019. Populasi pada penelitian ini adalah seluruh ibu hamil Trimester III sejumlah 57 orang di Wilayah kerja Puskesmas Klateng pada bulan Agustus 2019.

Teknik pengambilan sampel menggunakan purpo-sive sampling dengan kriteria inklusi ibu hamil sehat tanpa ada keluhan mual dan muntah. Jenis penelitian dan sampel minimum yang disarankan untuk penelitian eksperimen adalah 15 subyek per group. Dengan demikian besar sampel diperoleh adalah 30 sampel terbagi menjadi 2 yaitu 15 sampel sebagai kelompok kontrol dan 15 sampel sebagai kelompok perlakuan.

Pada penelitian ini, peneliti memberikan treatment pada kelompok eksperimen berupa konsumsi buah kurma yang dikonsumsi 7 butir perhari selama 14 hari,pada kelompok kontrol mengkonsumsi tablet Fe secara teratur.

Analisa data pada penelitian ini menggunakan statistik non parametric yaitu diuji dengan Wilcoxon Signed Rank Test untuk mengetahui pengaruh konsumsi buah, kurma terhadap peningkatan kadar haemoglobin. Pengujian dilakukan dengan bantuan program komputer SPSS 19.0 for windows.

\section{HASIL PENELITIAN}

Analisis univariat digunakan untuk mengetahui distribusi frekuensi, tendency central dan variasi data kadar haemoglobin pada kelompok konsumsi kurma maupun kelompok konsums tablet $\mathrm{Fe}$. 
Tabel 1. Distribusi Frekuensi Karakteristik Responden

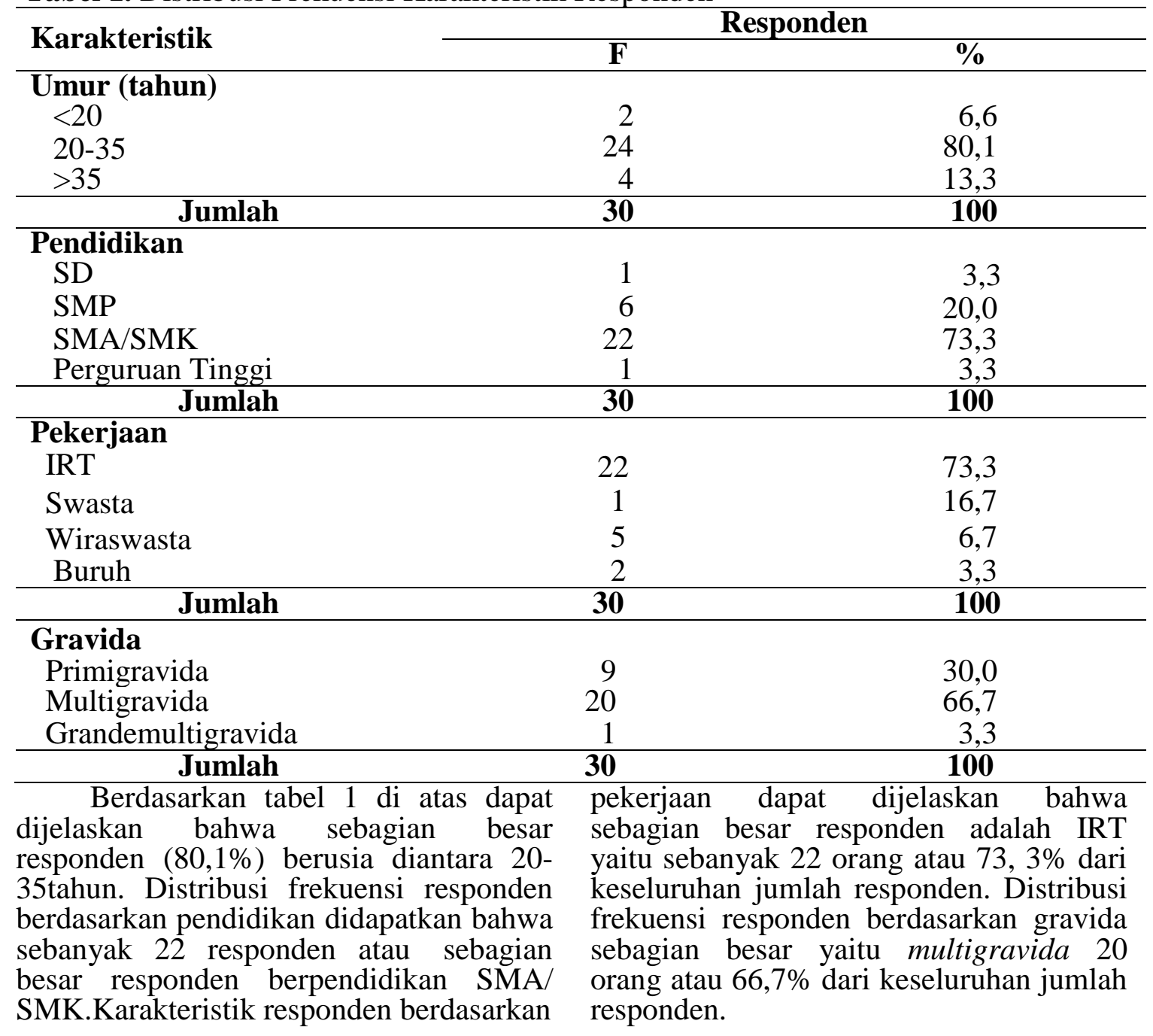

Tabel 2. Distribusi Frekuensi Karakteristik Responden

\begin{tabular}{|c|c|c|c|c|c|}
\hline \multirow[b]{2}{*}{ Pre Test } & \multicolumn{2}{|c|}{ Perlakuan } & \multirow{2}{*}{ Post Test } & \multicolumn{2}{|c|}{ Perlakuan } \\
\hline & $\mathbf{F}$ & $\%$ & & $\mathbf{F}$ & $\%$ \\
\hline 9,8 & 1 & 6.7 & 10,9 & 1 & 6.7 \\
\hline 9,8 & 1 & 6.7 & 11,1 & 2 & 13.3 \\
\hline 9,9 & 2 & 13.3 & 11,3 & 1 & 6.7 \\
\hline 10,0 & 1 & 6.7 & 11,4 & 1 & 6.7 \\
\hline 10,5 & 1 & 6.7 & 11,5 & 1 & 6.7 \\
\hline 10,7 & 1 & 6.7 & 11,6 & 2 & 13.3 \\
\hline 10,8 & 1 & 6.7 & 11,8 & 1 & 6.7 \\
\hline 10,9 & 1 & 6.7 & 12,0 & 1 & 6.7 \\
\hline 11,1 & 3 & 20.0 & 12,1 & 1 & 6.7 \\
\hline 11,4 & 1 & 6.7 & 12,6 & 1 & 6.7 \\
\hline 11,6 & 1 & 6.7 & 12,7 & 1 & 6.7 \\
\hline 13,4 & 1 & 6.7 & 13,2 & 1 & 6.7 \\
\hline & & & 14.0 & 1 & 6.7 \\
\hline
\end{tabular}




\begin{tabular}{lcclll}
\hline Total & $\mathbf{1 5}$ & $\mathbf{1 0 0 , 0}$ & Total & $\mathbf{1 5}$ & $\mathbf{1 0 0 , 0}$ \\
\hline Mean & 10,793 & & Mean & 11,933 & \\
Minimum & 9,8 & & Minimum & 10,9 & \\
Maximum & 13,3 & & Maximum & 14,0 & \\
Std. & 0,9490 & & Std. & 0,8981 & \\
\hline
\end{tabular}

Berdasarkan tabel 2, dapat dilihat responden atau 20,0\% dan hasil post test bahwa hasil pretest pada kelompok pada kelompok perlakuan frekuensi kadar perlakuan frekuensi kadar $\mathrm{Hb}$ paling $\mathrm{Hb}$ paling banyak yaitu $\mathrm{Hb} 11,1$ yaitu banyak yaitu $\mathrm{Hb}$ 11,1 yaitu sebanyak 3 sebanyak 2 responden atau 13,3\%

Tabel 3. Distribusi Frekuensi Kadar Hb Pre Test dan Post Test Pada Kelompok Kontrol Konsumsi Tablet Fe

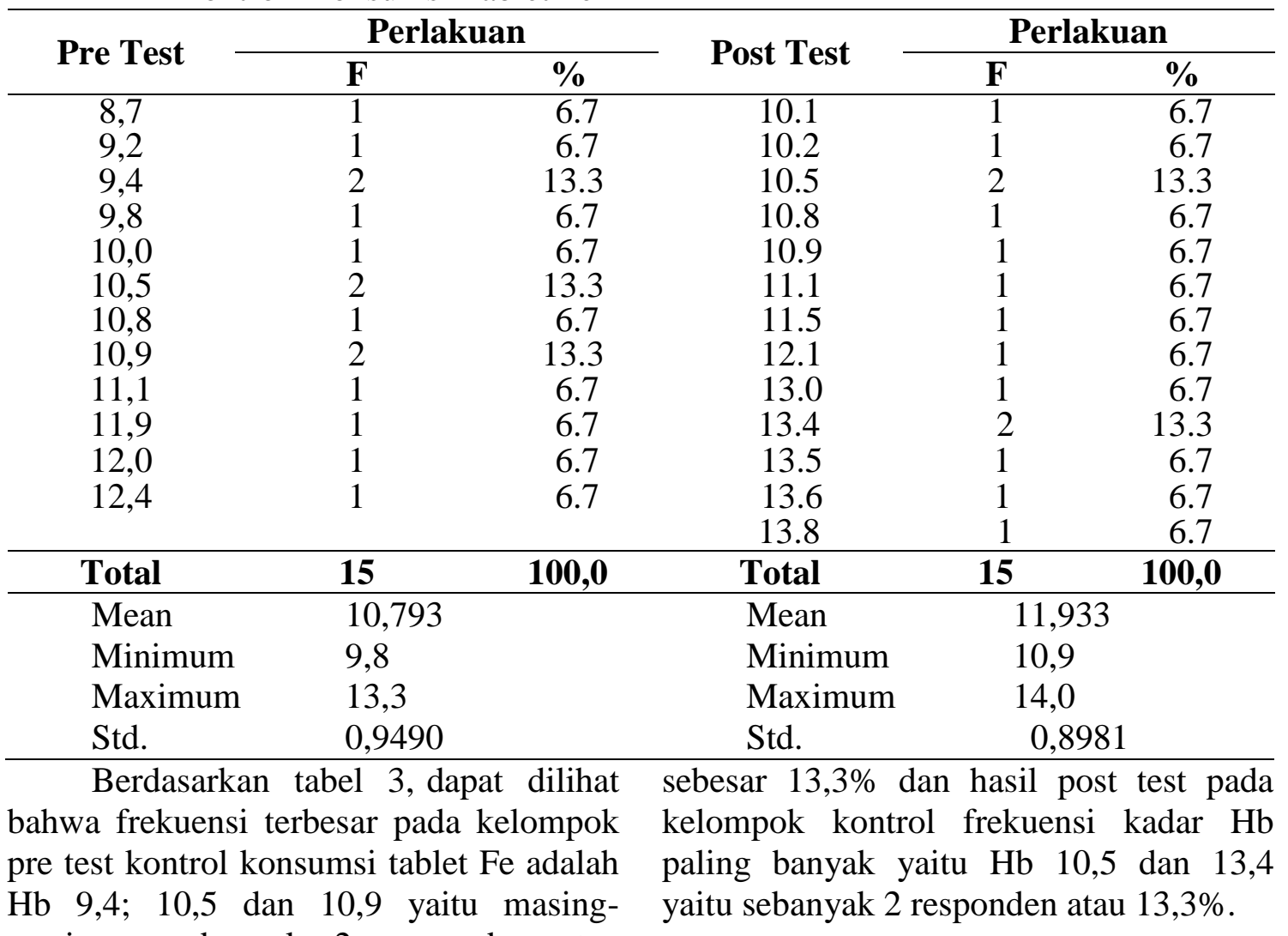
masing sebanyak 2 responden atau

Tabel 4. Distribusi Frekuensi Selisih Kadar Hb Pre dan Post Test (Peningkatan kadar $\mathrm{Hb}$ ) pada Kelompok Perlakuan dan Kelompok Kontrol

\begin{tabular}{ccccccc}
\hline \multirow{2}{*}{ Selisih Hb } & \multicolumn{2}{c}{ Perlakuan } & \multirow{2}{*}{ Selisih Hb } & \multicolumn{2}{c}{ Perlakuan } \\
\cline { 2 - 3 } & F & \% & & & F & \% \\
\hline 0,3 & 2 & 6.7 & 6.5 & 0.6 & 1 & 6.7 \\
0,4 & 2 & 3.3 & 0.7 & 1 & 6.7 \\
0,7 & 1 & 3.3 & 0.8 & 2 & 6.7 \\
0,8 & 1 & 6.7 & 0.9 & 2 & 13.3 \\
1,1 & 2 & & & & & 13.3
\end{tabular}




\begin{tabular}{llllll}
1,2 & 1 & 3.3 & 1.0 & 1 & 6.7 \\
1,3 & 1 & 3.3 & 1.4 & 1 & 6.7 \\
1,4 & 2 & 6.7 & 1.5 & 1 & 6.7 \\
1,6 & 1 & 3.3 & 1.6 & 1 & 6.7 \\
1,7 & 1 & 3.3 & 1,1 & 1 & 6.7 \\
1,8 & 1 & 3.3 & 1,2 & 2 & 13.3 \\
& & & 13,1 & 1 & 6,7 \\
\hline Total & $\mathbf{1 5}$ & $\mathbf{1 0 0 , 0}$ & Total & $\mathbf{1 5}$ & $\mathbf{1 0 0 , 0}$ \\
\hline Mean & 1,140 & & Mean & \multicolumn{2}{c}{1,393} \\
Minimum & 0,3 & & Minimum & 0,5 \\
Maximum & 1,8 & & Maximum & \multicolumn{2}{c}{1,6} \\
Std. & 0,66 & & Std. & \multicolumn{2}{c}{0,7458} \\
\hline
\end{tabular}

Berdasarkan tabel 4, nilai rata-rata post test pada kelompok kontrol dengan (Mean) Selisih (peningkatan kadar kadar Hemoglobin 1,393 gr/dL dan nilai hemoglobin) pre dan post test pada maksimum selisih (kenaikan kadar) kelompok perlakuan dengan kadar hemoglobin kelompok kontrol adalah 1,6 hemoglobin $1,140 \mathrm{~g} / \mathrm{dL}$ dan nilai gr/dl. Berdasarkan hasil uji normalitas, maksimum kenaikan kadar hemoglobin data terditsribusi tidak normal sehingga selisih kelompok perlakuan adalah 1,8 analisis bivariat menggunakan statistik $\mathrm{gr} / \mathrm{dL}$ serta nilai rata-rata (Mean) Selisih non parametrik dengan hasil sebagai (peningkatan kadar hemoglobin) pre dan berikut:

Tabel 5. Uji Wilcoxon Signed Rank Test Kadar Hemoglobin Sebelum dan Sesudah pada Kelompok Perlakuan dan Kelompok Kontrol

\begin{tabular}{lcccccc}
\hline Kelompok & N & Pre & Post & $\begin{array}{c}\Delta \\
\text { Mean }\end{array}$ & $\begin{array}{c}\text { Std. } \\
\text { Devi ation }\end{array}$ & $\begin{array}{c}\text { p value } \\
\text { (A.Sig. 2 tailed) }\end{array}$ \\
\hline Perlakukan & 15 & 10,793 & 11,933 & 1,140 & 0,6643 & 0,002 \\
Kontrol & 15 & 10,500 & 11,893 & 1,393 & 0,7458 & 0,002 \\
\hline
\end{tabular}

Berdasarkan tabel 5, terlihat bahwa rata-rata kadar hemoglobin pada kelompok perlakuan kadar hemoglobin pre (sebelum) pemberian kurma sebesar 10,793 dan post (setelah) pemberian kurma terjadi peningkatan sebesar 11,933 sehingga terlihat perbedaan dari nilai rata-rata pre dan post sebesar 1,140 dengan standar deviation 0,6643 . Hasil uji statistik didapatkan nilai $p$ value $<0,05(0,002<0,05)$ sehingga Ho ditolak, Ha diterima yang dapat disimpulkan, terdapat perbedaan kadar hemoglobin yang bermakna antara sebelum dan sesudah (pre test dan post test). Hal ini menjelaskan bahwa adanya pengaruh konsumsi buah kurma terhadap peningkatan kadar hemoglobin ibu hamil trimester III di wilayah kerja Puskesmas Klateng.

Pada kelompok kontrol rata-rata kadar hemoglobin pre sebesar 10,500 dan post sebesar 11,893 sehingga terlihat perbedaan nilai rata-rata pre dan post sebesar 1,393 dengan standar deviation 0,7458. Hasil uji statistik didapatkan $p$ value $<0,05(0,002<$ $0,05)$ sehingga dapat disimpulkan adanya perbedaan yang signifikan pada kelompok kontrol pre dan post. Hal ini menandakan bahwa adanya pengaruh pada kelompok kontrol (konsumsi Tablet Fe). 


\section{PEMBAHASAN}

Berdasarkan hasil analisis univariat Rerata kadar hemoglobin sebelum konsumsi kurma yaitu 10,793 gr/dl dan rerata kadar haemoglobin sesudah konsumsi kurma yaitu 11,933 gr/dl. Dapat dilihat bahwa terdapat peningkatan dari rerata dari sebelum dan sesudah pada kelompok perlakuan. Hasil penelitian ini sama dengan penelitian yang dilakukan oleh Sendra, E (2016) bahwa adanya peningkatan kadar $\mathrm{Hb}$ pada ibu hamil sebanyak $60 \%$ responden. Peningkatan kadar $\mathrm{Hb}$ dimungkinkan karena nutrisi yang adekuat ditambah dengan konsumsi kurma 25 gram/hari selama 30 hari serta konsumsi tablet Fe.

Menurut USDA (United States Departement and Agriculuture) National Nutrient Database for standard reference, kurma memiliki beberapa komponen penting yang dapat meningkatkan kadar haemoglobin bagi yang mengkonsumsinya. Kurma seberat 100 gr mengandung 2,81 gram protein, 7,1 gram serat, kalsium $35 \mathrm{mg}$, karbohidrat 88,78 gram, vitamin C 0,4 mg dan zat besi 1,02 mg. zat besi merupakan komponen dari haemoglobin di dalam sel darah merah yang menentukan daya dukung oksigen darah dan membantu mengatasi anemia.

Berdasarkan uji statistik yang telah dilakukan menunjukan bahwa rata-rata kadar hemoglobin ibu hamil pada kelompok perlakuan sebelum adalah $10,793 \mathrm{~g} / \mathrm{dL}$. Rata- rata kadar hemoglobin sesudah konsumsi buah kurma adalah 11,933 g/ dL sehingga terlihat perbedaan dari nilai rata-rata pre dan post sebesar 1,140 dengan standar deviation 0,6643. Hasil uji statistik didapatkan nilai $\mathrm{p}$ value $<0,05(0,002<$ 0,05) sehingga Ho ditolak, Ha diterima yang dapat disimpulkan, terdapat perbedaan kadar hemoglobin yang bermakna antara sebelum dan sesudah (pre test dan post test). Hal ini menjelaskan bahwa adanya pengaruh konsumsi buah kurma terhadap peningkatan kadar he- moglobin ibu hamil trimester III di wilayah kerja Puskesmas Klateng.

Hasil dari penelitian ini sama dengan beberapa penelitian yang diantaranya dilakukan oleh Susilowati D.A tahun 2017 dan Choliyah, N (2017) Hasil penelitian- penelitian tersebut mengatakan adanya pengaruh konsumsi buah kurma terhadap peningkatan kadar hemoglobin ibu hamil. Namun, pada penelitian Sendra, Eny (2017) berbeda yaitu tidak ada pengaruh konsumsi buah kurma terhadap peningkatan kadar hemoglobin ibu hamil.
Susilowati
D.A

mengemukakan bahwa hasil penelitiannya pada kelompok eksperimen atau yang diberikan buah kurma secara statistik memberikan pengaruh terhadap kadar hemoglobin ibu hamil. Sementara pada kelompok kontrol di dapatkan hasil adanya pengaruh pemberian tablet besi terhadap kadar hemoglobin pada kelompok kontrol. Pemberian suplemen zat besi dapat memperbaiki status besi tubuh ibu hamil.

Berdasarkan penelitian yang telah dilakukan didapatkan bahwa adanya pengaruh dari selisih kadar hemoglobin dari kedua kelompok. Oleh karena itu, kurma dapat dijadikan sebagai salah satu alternative pilihan dalam memenuhi kebutuhan zat besi selama kehamilan.

Hal ini sesuai dengan Penelitian sebelumnya yang dilakukan oleh Anita (2013), membuktikan bahwa pemberian sari kurma berpengaruh terhadap kadar 
hemoglobin. Hasil ini menunjukkan bahwa sari kurma yang kaya akan zat besi dapat meningkatkan kadar hemoglobin. Kandungan protein, karbohidrat, dan lemak pada sari kurma serta kandungan glukosa, $\mathrm{Ca}, \mathrm{Fe}, \mathrm{Zn}, \mathrm{Cu}, \mathrm{P}$, dan Niasin dengan palmyra yang kaya kandungan Vit A mendukung sintesis hemoglobin, Kandungan sari kurma yang secara tidak langsung juga dapat meningkatkan jumlah trombosit yaitu zat mineral seperti zat besi yang essensial bagi pembentukan hemoglobin. Besi yang segera dibutuhkan untuk produksi sel darah merah diserap ke dalam darah untuk disalurkan ke sumsum tulang dan akan digunakan untuk membentuk hemoglobin bagi sel darah merah baru yang akan mengikat oksigen untuk kebutuhan metabolisme sel terutama ke hati sehingga hati dapat melaksanakan fungsinya dengan baik termasuk menghasilkan hormon trombopoietin.

Namun, hasil penelitian ini tidak sejalan dengan penelitian yang dilakukan oleh Sendra, E (2016) yang dilakukan pada ibu hamil dengan judul Pengaruh Konsumsi Kurma (Phoenix Dactylifera) Terhadap Kenaikan Kadar Hemoglobin Pada Ibu Hamil Trimester II Di Wilayah Puskesmas Kediri, pada penelitian tersebut tidak ada pengaruh

\section{KESIMPULAN DAN SARAN}

Pada penelitian ini konsumsi buah kurma berpengaruh pada peningkatan kadar hemoglobin ibu hamil trimester III. Buah kurma memiliki berbagai macam zat gizi yang baik termasuk zat besi untuk meningkatkan kadar Hb.

Dengan mengkonsumsi buah kurma bagi ibu hamil yang tidak konsumsi tablet kenaikan kadar hemoglobin trimester II yang mengkonsumsi kurma, namun dalam penelitian tersebut menyebutkan bahwa ibu yang mengkonsumsi buah kurma sebanyak 25 gram/hari mengalami kenaikan kadar hemoglobin pada ibu hamil hingga $60 \%$ sementara sisanya $40 \%$ ibu mengalami penurunan atau bahkan tetap. Uji statistik menggunakan paired ttest khusus untuk kelompok pemberian kurma didapatkan hasil nilai $\mathrm{p}$ value $=$ 0,301 yang lebih besar dari alpha $(0,05)$ yang berarti tidak ada perbedaan sebelum diberikan kurma dan setelah diberikan kurma. Dilihat dari data ada yang menurun, ada yang tetap dan ada yang naik sehingga kurma tidak memberikan efek terhadap $\mathrm{Hb}$. Menurut Satuhu (2010) salah satu manfaat buah kurma dalam bidang medis diantaranya yaitu mengurangi resiko anemia. Kurma mengandung mineral yang dibutuhkan oelh tubuh, misalnya zat besi, magnesium, kalium. Zat besi sangat penting untuk mencegah terjadinya anemia, gejala anemia sendiri adalah mudah lelah, pusing, pandangan kabur dan kesulitan berkonsentrasi. Menurut Proverawati (2011) Pada ibu hamil yang mengalami anemia dikarenakan kurangnya zat besi dapat berdampak pada kehamilan, persalinan dan janin.

penambah darah atau tablet $\mathrm{Fe}$ dapat menjadikan buah kurma sebagai alternatif untuk memenuhi kebutuhan zat besi sehingga dapat terhindar dari anemia. Diharapkan pada penelitian selanjutnya untuk menambah jumlah subjek dan lama waktu konsumsi serta menghindari faktor biasa seperti pola konsumsi makanan. 


\section{DAFTAR RUJUKAN}

Almatsier. Sunita. (2009). Prinsip Dasar Ilmu Gizi. Jakarta: Pustaka Utama.

Anita, P. (2013). Pengaruh Pemberian Sari Kurma Terhadap Peningkatan Kadar Hemoglobin pada Pasien Anemia di BRSD Luwuk. Jurnal Kesehatan.

An-Nawawi, I. (2015). Riyadhus Shalihin. Solo: Insan Kamil Solo

Apriyanti, M, (2012). Sepuluh Tanaman Obat Paling Berkhasiat dan Paling Dicari. Yogyakarta: Pustaka Baru Press.

Ashraf, Z \& Hamidi-Esfahani, Z (2011). Date and date processing: a review. Food reviews International, 27 (2): 101-133

Asmadi. (2008). Teknik Prosedural Keperawatan Konsep dan Aplikasi Kebutuhan Dasar Klien. Jakarta: Salemba Medika.

Badan Penelitian Dan Pengembangan Kesehatan Kementerian Kesehatan RI. (2013). RISKESDAS. Jakarta: Kemenkes RI

Budiana, dkk. (2013). Buah Ajaib Tumpas Penyakit. Jakarta : Penebar Swadaya.

Cholifah, Noor. (2017). Aplikasi Pemberian Kurma Sebagai Upaya Peningkatan Kadar Hemoglobin Pada Remaja Putri Yang Mengalami Anemia. THE 5TH URECOL PROCEEDING.http://lpp.uad.ac.id/ wp-content /uploads/2017/05/49.- noor-choliyah-381-387.pdf diakses pada tanggal 27 Desember 2017

Cidadapi. (2014). Ramuan Herbal Ala Thibun Nabawi Mengupas Pengobatan Herbal di Dalam Thibun Nabawi. Jakarta: Putra Danayu

Dahlan, Muhammad Sopiyudin. (2015). Statistik untuk Kedokteran dan Kesehatan: Deskriptif, Bivariat, dan Multivariat Dilengkapi Aplikasi Menggunakan SPSS. Jakarta Pusat: Epidemiologi Indonesia

Gibney, M.J. dkk. (2009). Gizi Kesehatan Masyarakat. Jakarta: EGC

Istiqomah. (2016). Pengaruh Pemberian Kurma Terhadap Kadar Hemoglobin Ibu Hamil Trimester II di Bidan Praktik Mandiri " $M$ " Kalasan Sleman Yogyakarta. Universitas Aisyah Yogyakarta

Kasjono dan Yasril. (2009). Teknik Sampling untuk Penelitian Kesehatan. Yogyakarta: Graha Ilmu

Manuaba, I.B.G. (2010). Ilmu Kebidanan, Penyakit Kandungan dan Keluarga Berencana untuk Pendidikan Bidan. Jakarta: EGC

Notoatmodjo, S. (2012). Metodologi Penelitian Kesehatan. Jakarta: PT Rineka Cipta

Nursalam. (2014). Metodologi Penelitian Ilmu Keperawatan. Jakarta: Salemba Medika 
Pearce E.C. (2009). Anatomi dan fisiologi untuk paramedic. Jakarta: PT. Gramedia

Prawirohardjo,S. (2010). Pelayanan Kesehatan Maternal dan Neonatal. Jakarta : Bina Pustaka.

Proverawati, A dan Asfuah, S. (2009). Buku Ajar Gizi untuk Kebidanan. Yogyakarta: Nuha Medika

Proverawati, A. (2011). Anemia dan Anemia dalam Kehamilan. Yogyakarta: Nuha Medika

Pudiastuti, Dewi Ratna. (2012). Asuhan Kebidanan pada Hamil Normal dan Patologi. Yogyakarta: Nuha Medika.

Rostita. (2009). Khasiat dan Keajaiban Kurma. Bandung: Penerbit Qanita

Satuhu, Suyanti. (2010). Kurma Khasiat dan Olahannya. Jakarta:Penebar Swadaya.

Sendra, Eny. (2016). Pengaruh Konsumsi Kurma (Phoenix dactylifera) Terhadap Kenaikan Kadar Hemoglobin Pada Ibu Hamil Trimester II Di Wilayah Puskesmas Kediri. Jurnal Ilmu Kesehatan Vol. 5 no.1 Nopember 2016.http://ejurnaladhkdr.com/index .php/coba/article/download/119/100/ diakses pada tanggal 27 Desember 2017

Setiawan,A,dkk. (2013). Hubungan Kadar Hemoglobin Ibu Hamil Trimester III Dengan Berat Bayi Lahir di Kota
Pariaman. Jurnal Kesehatan Andalas. Vol 2.No 1.

Sofro, Abdul Salam M. (2012). Darah Pustaka Pelajar, Yogyakarta.

Sugiyono. (2012). Statistika Untuk Penelitian. Bandung: Alfabeta.

Susilowati,D.A. (2017). Pengaruh Pemberian Buah Kurma Pada Ibu Hamil TMIII dengan Anemia Terhadap Kadar Hemoglobin di BPM Tri Rahayu Setyaningsih Cangkringan Sleman Yogyakarta. http://digilib.unisayogya.ac.id/2685/ 1/NASKAH\%20PUBLIKASI_\%20 Diyah\%20ayu\%20susilowati.pdf Diakses pada tanggal 27 Desember 2017

Tamizi, S.M., Suliaman, I. \& Ibrahim, H. (2014). The Prophetic Tradition and Nutrition: Issues of mixing raisins and dates. Online Journal of Research In Islam Studies, 1(2).

Waryana. (2010). Gizi Reproduksi. Yogyakarta: Pustaka Rihama

World Health Organization.(2011). Haemoglobin Concentrations for The Diagnosis of Anaemia and Assessment of Severity. Available from:

http://apps.who.int/iris/bitstream/10 665/85839/3/WHO_NMH_NHD_M NM_11.1_eng.pdf 